\title{
PENGARUH KUALITAS PELAYANAN TERHADAP KEPUASAN PELANGGAN DI PT.POS INDONESIA (PERSERO) CABANG SOREANG 40900
}

\author{
DADANG CAHYANA \\ Politeknik Piksi Ganesha \\ (dadang.cahyana@yahoo.com)
}

\begin{abstract}
ABSTRAK
Penelitian ini bertujuan untuk mengetahui bagaimana pengaruh kualitas pelayanan terhadap kepuasan nasabah di PT. POS INDONESIA (PERSERO) Cabang Soreang 40900.

Metode yang digunakan adalah metode kuantitatif dan teknik pengumpulan data dengan cara wawancara, observasi, penyebaran angket dan kajian pustaka yang memiliki hubungan erat dengan pokok permasalahan.

Dari hasil penelitian diperoleh nilai koefisien korelasi Rank Spearman antara kualitas pelayanan terhadap kepuasan pelangan adalah 0.955 dan koefisien determinasi sebesar $91.33 \%$ hal ini dapat dikatakan hubungan antara pengaruh kualitas pelayanan terhadap kepuasan pelanggan termasuk kategori sangat kuat.

Dari penelitian yang dilakukan ternyata ditemukan permasalahan dalam pengaruh kualitas pelayanan terhadap kepuasan pelanggan antara lain 1). Pada pelayanan I-Pos atau pelayanan surat menyurat masih banyak konsumen yang kurang memahami tentang standarisasi pengiriman surat, dokumen, dan berang, 2). Belum tersedianya kotak saran maupu keluhan untuk konsumen.

Adapun saran yang diberikan diantaranya : 1). Memasang papan informasi yang berisi prosedur prosedur yang ada di PT. POS INDONESIA, 2). Disediakannya kotak saran maupun keluhan untuk konsumen.
\end{abstract}

\section{A. PENDAHULUAN}

Jumlah penduduk Indonesia yang sangat besar menjadi pasar yang sangat potensial bagi perusahaan-perusahaan untuk memasarkan produk-produk perusahaan tersebut. Perusahaan milik pemerintah, swasta maupun perusahaan asing berusaha mendirikan usaha bisnis dan menciptakan jenis-jenis produk baik berupa barang maupun jasa yang nantinya akan digemari oleh calon pelanggan. Banyaknya perusahaan ini menciptakan adanya suatu persaingan bisnis apabila perusahaan mampu menjaring pelanggan sebanyak-banyaknya maka perusahaan dapat memperoleh keuntungan yang besar pula. (Veranita, 2012)

Dalam kondisi persaingan yang ketat tersebut, hal utama yang harus diprioritaskan oleh perusahaan adalah kepuasan pelanggan agar dapat bertahan, bersaing dan menguasai pasar. Kepuasan pelanggan ditentukan oleh kualitas pelayanan yang baik, sehingga jaminan produk menjadi prioritas utama bagi setiap perusahaan yang ada pada saat ini khususnya dijadikan sebagai tolok ukur keungggulan daya saing perusahaan.

Kualitas bermula dari kebutuhan pelanggan yang diteruskan pada persepsi konsumen / pelanggan. Dalam hal ini berarti sebuah kualitas merupakan penilaian menyeluruh dari konsumen / pelanggan atas keunggulan suatu pelayanan. Dengan demikian terlihat jelas bahwa kualitas pelayanan berkaitan erat dengan kepuasan konsumen / pelanggan.

Tujuan utama perusahaan yang bergerak di bidang jasa adalah menciptakan dan mempertahankan konsumen/pelanggan. Pelayanan prima (service excellence) suatu perusahaan dinilai baik apabila pelanggan atau nasabah pemakai produk atau jasa selalu mendapatkan kepuasan, dan dari kepuasan itulah diharapkan konsumen/pelanggan akan terus loyal terhadap perusahaan. Saat ini seringkali ditemui konsumen / pelanggan memutuskan untuk tidak menggunakan produk / jasa yang diberikan oleh sebuah perusahan jasa bahkan memutuskan hubungan dengan pemberi jasa tersebut karena rendahnya kualitas pelayanan prima yang diberikan oleh perusahaan jasa tersebut. Maka dari itu kualitas pelayanan sangat berpengaruh terhadap kepuasan pelanggan. (Susilowati, 2018)

PT. POS INDONESIA sebagai satu - satunya perusahaan milik negara yang menangani jasa pengiriman surat dan barang serta layanan lainnya antar wilayah dituntut untuk terus meningkatkan kualitas layanan yang ada sehingga dapat terus bersaing dengan perusahaan - perusahaan sejenis yang ada di Indonesia. Dalam rangka meningkatkan kualitas pelayanan kepada calon konsumen, baik penyediaan kebutuhan konsumen akan pengiriman surat dan kiriman express dan lainnya maka perusahaan memperluas jaringan dalam 
melaksanakan dan meningkatkan mutu pelayanan bagi pelanggan POS dalam

Dalam kegiatan usahanya PT. POS Cabang Soreang tidak lepas dari masalah, masalah yang sering timbul adalah belum tersedianya kotak saran maupun survey kepuasan pelanggan hal ini mengakibatkan perusahaan sulit untuk mengukur kinerja dan tidak dapat mengetahui hal - hal apa saja yang diharapkan oleh pelanggan. Masalah tersebut diduga disebabkan oleh belum adanya sistem untuk menerima keluhan pelanggan dan upaya mengatasi keluhan pelanggan.

\section{B. KAJIAN PUSTAKA}

Davis, ( dalam Zulian Yamit, 2005 : 8 ) membuat definisi kualitas yang lebih luas cakupannya, yaitu atau kualitas merupakan suatu kondisi dinamis yang berhubungan dengan produk, jasa, manusia, proses, dan lingkungan yang memenuhi atau melebihi harapan.

Pendekatan yang digunakan Goetsch Davis ini menegaskan bahwa kualitas bukan hanya menekankan pada aspek hasil akhir, yaitu produk dan jasa tetapi juga menyangkut kualitas manusia, kualitas lingkungan. Sangatlah mustahil menghasilkan produk dan jasa yang berkualitas tanpa melalui manusia dan proses yang berkualitas.

Menurut Philip Kotler (2000 : 465) “Kualitas adalah sebuah kata yang bagi penyedia jasa merupakan sesuatu yang harus dikerjakan dengan baik".

Kualitas Total adalah kunci untuk menciptakan nilai dan kepuasan, oleh karena itu para marketing mamajer harus terus berupaya merumuskan, memikirkan, dan melaksanakan suatu strategi yang akurat untuk menciptakan kualitas total.

Kualitas sering dianggap sebagai ukuran relative kebaikan suatu produk atau jasa yang terdiri atas kualitas desain dan kualitas kesesuain. Menurut Fandy Tjipto ( 2006 : 51 ) ada 5 macam perspektif kualitas, yaitu :

1. Transcendental approach

2. Product-based approach

3. User-based approch

4. Manufacturing-based approach

Pengertian dari 5 macam perspektif kualitas, yaitu :

1. Transcendental approach

Kulitas dipandang sebagai innate excellence, dimana kualitas dapat dirasakan atau diketahui tetapi sulit didefinisikan atau dioperasionalisasikan biasanya diterapkan dalam dunia seni.

2. Product-based approach

Kualitas merupakan karakteristik atau atribut yang dapat dikuantitatifkan dan dapat diukur. Perbadaan dalam kualitas mencerminkan perbedaan dalam jumlah beberapa unsur atau atribut yang dimiliki produk.

3. User-based approch

Kualitas bergantung pada orang yang memandangnya, sehingga produk yang paling memuaskan preferensi seseorang.
4. Manufacturing-based approach

Kualitas sebagai kesesuian / sama dengan persyaratan. Dalam sector jasa bahwa kualitas seringkali didorong oleh tujuan peningkatan produktivitas dan penekanan biaya.

5. Value-based approach

Kualitas dipandang dari segi nilai dan harga. Kualitas dalam pengertian ini bersifat relatif, sehingga produk yang memiliki kualitas paling tinggi belum tentu produk yang paling bernilai. Akan tetapi yang paling bernilai adalah barang atau jasa yang paling tepat dibeli.

Berdasarkan beberapa pengertian kualitas dapat diartikan bahwa kualitas hidup kerja harus merupakan suatu pola pikir ( mindset), yang dapat menterjemahkan tuntunan dan kebutuhan pasar konsumen dalam suatu proses manajemem dan proses produksi barang atau jasa terus menerus tanpa hentinya sehingga memenuhi persepsi kualitas pasar konsumen tersebut.

Kualitas memiliki hubungan erat dengan kepuasan konsumen, kualitas memberikan suatu dorongan kepada konsumen untuk menjalin ikatan hubungan yang kuat dengan perusahaan. Dalam jangka panjang ikatan seperti ini memungkinkan perusahaan untuk memahami seksama, Dengan demikian perusahaan dapat meningkatkan kepuasan pelanggan, dimana perusahaan memaksimumkan pengalaman pelanggan yang menyenangkan dan meminimumkan pengalaman pelanggan yang kurang menyenangkan. Pada gilirannya kepuasan pelanggan dapat menciptakan kesetiaan dan loyalitas pelanggan kepada perusahaan.

Selain itu, perusahaan juga dapat meningkatkan pesaing pasarnya melalui pemenuhan kualitas yang bersifat customer-driven yang artinya peningkatan daya saing berkelanjutan dalam organisasi yang mengupayakan pemenuhan kualitas. Hal ini akan mengunggulkan harga dan customer value. Customer value adalah merupakan kombinasi dari manfaat dan memahami yang terjadi apabila konsumen menggunakan suatu barang atau jasa guna memenuhi kebutuhan tertentu. Bila kualitas yang dihasilkan pangsa pasar yang dimiliki besar maka profitabilitasnya terjamin, jadi kualitas dan profitabilitas berkaitan erat.

Perusahaan yang menawarkan barang dan jasa berkualitas superior berati dapat mengalahkan pesaingnya yang dihasilkan kualitas inflerior Kualitas juga dapat mengurangi biaya, adanya pengurangan biaya ini pada gilirannya akan memberikan keunggualan kompetesi tanpa peningkatan profitabilitas dan pertumbuhan.

\section{Pelayanan}

Menurut A.S Moenir (2001:26) mendefinisikan "Pelayanan adalah kegiatan yang dilakukan oleh seseorang atau sekelompok orang dengan

landasan faktor material melalui sistem, prosedur, dan metode tertentu, dalam rangka usaha memenuhi kepentingan orang lain sesuai dengan hak-haknya". 
Menurut Rambat Lupioyadi (2001:143) mendefinisikan "Pelayanan adalah suatu tindakan yang dilakukan untuk memenuhi apa yang diinginkan oleh pelanggan.

Dari definisi di atas dapat disimpulkan bahwa pelayanan terhadap pelanggan merupakan suatu aktivitas atau kegiatan yang dilakukan untuk orang lain, oleh seseorang atau suatu organisasi melalui prosedur tertentu, sehingga keinginan pelanggan dapat terpenuhi sesuai dengan kebutuhannya

Menurut Swastika (2005:3) mengemukakan bahwa Pelayanan Prima (service excellence) mengandung 3 hal pokok yaitu adanya pendekatan sikap yang berkaitan dengan kepedulian kepada pelanggan, upaya melayani dengan tindakan yang terbaik dan ada tujuan untuk memuaskan pelanggan dengan berorientasi pasa standar layanan tertentu.

Menurut Barata (2004:31) pelayanan prima (service excellence) terdiri dari 6 unsur pokok, antara lain:

1. Kemampuan (Ability)

2. Sikap (Attitude)

3. Penampilan (Appearance)

4. Perhatian (Attention)

5. Tindakan (Action)

6. Tanggung jawab (Accounttability)

Pengertian unsur-unsur dalam pelayanan prima

1. Pengertian kemampuan (Ability)

Menurut Robbins (2000) "Kemampuan merupakan kesanggupan bawaan seseorang sejak lahir, atau merupakan hasil latihan atau praktek yng terdiri dari (kemampuan, kecakapan, ketangkasan, bakat, kesanggupan)".

Dari pengertian tersebut dapat disimpulkan bahwa kemampuan (Ability) adalah kecakapan atau potensi menguasai suatu keahlian yang merupakan bawaan sejak lahir atau merupakan hasil latihan atau praktek dan digunakan untuk mengrjakan sesuatu yang diwujudkan melalui tindakannya.

2. Pengertian Sikap (Attitude)

Sikap adalah sesuatu yang berbentuk dalaman dan sukar untuk dipahami.Sikap terletak dalam sanubari manusia. Sikap pelayanan yang diharapkan tertanam pada diri para karyawan adalah sikap yang baik, ramah, penuh simpatik, dan mempunyai rasa memiliki yang tinggi terhadap perusahaan. Jika kalian menjadi karyawan suatu perusahaan, sikap kalian akan menggambarkan perusahaan kalian. Kalian akan mewakili citra perusahaan baik secara langsung atau tidak langsung. Pelanggan akan menilai perusahaan dari kesan pertama dalam berhubungan dengan orang-orang yang terlibat dalam perusahaan tersebut.

3. Pengertian Penampilan (Appearance)

Penampilan adalah suatu bentuk ciri diri yang terdampar dalam diri seseorang dan merupakan sarana komunikasi diri kita dengan orang lain. Berpenampilan menarik adalah salah satu bagian dari kunci sukses dalam bekerja, terutama pekerjaan yang berhubungan dengan orang lain. Penampilan diri yang baik adalah perpaduan dari keserasian penampilan luar (Fisik) dan penampilan yang timbul dari dalam diri kita (Rohani). Penampilan luar dengan barang-barang yang mewah yang menempel pada tubuh kita akan berarti apa-apa jika kondisi tubuh kita tidak sehat (tampak lusuh dan loyo).

4. Pengertian Perhatian (Attention)

Dalam melakukan kegiatan layanan, seoarang petugas pada perusahaan industri jasa pelayanan harus senantiasa memperhatikan dan mencermati keinginan pelanggan. Apabila pelanggan sudah menunjukan minat untuk membeli suatu barang / jasa yang kita tawarkan, segera saja layani pelanggan tersebut dan tawarkan bantuan, sehingga pelanggan merasa puas dan terpenuhi barang / jasa yang kita tawarkan, segera saja layani pelanggan tersebut dan tawarkan bantuan, sehingga pelanggan merasa puas dan terpenuhi keinginannya.

5. Pengertian Tindakan (Action)

Pada konsep perhatian, pelanggan "menjatuhkan minat" untuk membeli produk yang kita tawarkan. Pada konsep tindakan pelanggan sudah "menjatuhkan pilihan" untuk membeli produk yang diinginkannyauntuk membeli produk yang diinginkannya, Terciptanya proses komunikasi pada konsep tindakan ini merupakan tanggapan terhadappelanggan yang telah menjatuhkan pilihannya, sehingga terjadilah transaksi jual beli.

6. Pengertian Tanggung jawab (Accountability) Tanggung jawab adalah keadaan wajib menanggung segala sesuatu. Sehingga bertanggung jawab merupakan berkewajiban menanggung, memikul jawab, menanggung segala sasuatunya sebagai kesadaran dan kewajibannya.

Setelah menyimak pengertian diatas, maka dapat diketahui ciri pokok pelayanan adalah tidak dapat diraba dan melihat upaya manusia atau seorang karyawan dan peralatan yang lain yang sudah disediakan oleh perusahaan penyelenggara pelayanan. Hal-hal yang tidak dapat diraba yang merupakan ciri-ciri dari pelayanan berkenaan dengan sisi manusiawi organisasi, hal ini mencakup emosi, perilaku, pemahaman, perasaan, persepsi manusia. Hal-hal yang tidak baik kasat mata atau tidak dapat diraba, sering kali sulit dipahami karena dalam kegiatan pelayanan orangnya perlu memeriksa, menyentuh, ataupun menciumnya untuk menentukan apa "benar" atau "salah". Walaupun begitu pelayanan konsumen yang tidak kasat mata atau tidak dapat diraba sering kali sebagai kunci dari suatu keberhasilan organisasi.

\section{Proses Pelayanan}

Menurut Gibson, Invancenvich \& Donnelly (2001) pada 
dasarnya proses pelayanan dapat terjadi antara:

a. Responsivitas

b. Responsibilitas

c. Akuntabilitas

d. Keadaptasian

e. Kelangsungan Hidup

f. Keterbukaan / Transparansi

g. Empathi

Proses pelayanan adalah meliputi :

a. Responsivitas

Merupakan kemampuan provider untuk mengenali

kebutuhan masyarakat, menyusun agenda dan prioritas pelayanan, serta mengembangkan program - program pelayanan sesuai dengan kebutuhan dan aspirasi masyarakat.

b. Responsibilitas

Yaitu ukuran yang mengajukan seberapa besar tingkat kesesuaian antara penyelenggaraan pemerintahan dengan hukum atau peraturan dan prosedur yang telah ditetapkan.

c. Akuntabilitas

Suatu ukuran yang menunjukan seberapa besar tingkat kesesuaian antara penyelenggaraan pemerintahan dengan ukuran-ukuran eksternal yang ada di masyarakat dan dimiliki oleh stake holders, seperti nilai dan norma yang berkembang dalam masyarakat.

d. Keadaptasian

Adalah ukuran yang menunjukan daya tanggap organisasi terhadap tuntutan perubahan yang terjadi di lingkungan masyarakat.

e. Kelangsungan Hidup

Seberapa jauh pemerintah daerah atau program pelayanan dapat menunjukan kemampuan untuk terus berkembang dan bertahan hidup dalam berkompetisi dengan daerah atau program yang lain.

f. Keterbukaan / Transparansi

Suatu prosedur tatacara, penyelenggaraan pemerintahan dan hal-hal lain yang berkaitan dengan proses pelayanan umum, wajib di informasikan secara terbuka agar mudah diketahui dan difahami oleh masyarakat lain, baik diminta maupun tidak diminta.

g. Empathi

Perlakuan perhatian pemerintah daerah atau penyelenggaraan jasa pelayanan atau provider terhadap isu-isu aktual yang sedang berkembang di kalangan masyarakat.

\section{Strategi Pelayanan}

Langkah atau sikap yang harus dimiliki oleh pihak perusahaan sehubungan dengan stategi pelayanan menurut Wira Suteja (2007 : 20), yaitu:

a. Sediakan waktu untuk mencari tahu apa yang dibutuhkan pelanggan

b. Siapkan fasilitas yang mendukung permintaan pelanggan c. Sampaikan sikap positif dimata pelanggan

d. Kenali kebutuhan pelanggan

e. Selalu penuhi kebutuhan pelanggan

f. Pastikan pelanggan kembali lagi

Cara-cara Menarik dan Menyenangkan Pelanggan.

Wira Suteja (2007:30) mengemukakan beberapa cara untuk menarik atau menyenangkan pelanggan yaitu diantaranya :

a. Murah Senyum

b. Ramah, Sopan, dan Bersedia Membantu

c. Bekerja dengan Giat

d. Optimis

e. Bersikap Antusias dan Bergairah

f. Imajinasi

g. Jadilah Orang yang Fleksibel

h. Penilaian

Untuk menarik atau menyenangkan pelangga adalah :

a. Murah Senyum

Tidak ada yang lebih baik dari pada tegur sapa yang ramah dan senyuman yang menawan

b. Ramah, Sopan, dan Bersedia Membantu

Berbicara dan memperlakukan pelanggan seolah-olah pelanggan adalah kekasih kita yang harus kita layani dengan sepenuh hati dan tulus, dan buat mereka percaya pada kita bahwa apa yang kita kerjakan adalah benar dan sungguh-sungguh.

c. Bekerja dengan Giat

Tanpa kerja keras, hal sekecil apapun akan menjadi masalah dan menghambat pekerjaan kita

d. Optimis

Selalu berfikiran positif, tidak peduli seberapa ukurannya situasi yang sedang kita hadapi

e. Bersikap Antusias dan Bergairah

Kegairahan selalu menghasilkan kreatifitas dan ide-ide cemerlang pada saat melakukan suatu pekerjaan, cobalah untuk serius dan tertarik dalam melayani pelanggan.

f. Imajinasi

Janganlah takut untuk mencoba cara atau sistem kita sendiri, selama itu dapat memperlancar dan mempermudah tugas kita dan tidak merugikan perusahaan. Pelanggan akan menghargai kreatifitas kita.

g. Jadilah Orang yang Fleksibel

Kemampuan untuk mempunyai pendirian yang teguh, tetap fleksibel, tidak kaku disaat menghadapi pelanggan, dan dapat menyesuaikan diri dengan keadaan yang berubah-ubah.

h. Penilaian

Kemampuan untuk mengimbangi kenyataan dan membuat kesimpulan yang rasional atau masuk akal, pertimbangkanlah selalu apa yang menjadi pendapat orang lain

Tingkat pemberian pelayanan kepuasan kepada pelanggan kita, dapat dikelompokan sebagai berikut:

1. Self Awareness

2. Anthusiasm 
3. Reform

4. Value

5. Impressive

6. Care

7. Evaluation

Pengertian dari tingkat palayanan kepuasan pelanggan adalah sebagai berikut :

1. Self Awareness adalah kesadaran pribadi untuk memberikan pelayanan yang maksimal dan sebaik mungkin kepada pelanggan

2. Anthusiasm adalah memberikan pelayanan dengan penuh antusias, dan melakukannya dengan gairah semangat tidak loyo

3. Reform adalah memperbaiki dan meningkatkan kinerja para karyawan untuk melayani pelanggan dari waktu ke waktu serta dari hari ke hari

4. Value adalah alat utama dalam mengidentifikasikan sumber-sumber potensial peningkatan nilai

5. Impressive adalah pelayanan harus menarik mungkin, berkesan, namun tidak berlebihan

6. Care adalah memberikan perhatian dan kepedulian terhadap pelanggan secara optimal dan maksimal

7. Evaluation adalah pelayanan yang telah diberikan harus dievaluasikan dan didiskusikan kembali.

\section{Kualitas Pelayanan}

"Kualitas pelayanan merupakan suatu pernyataan tentang sikap, hubungan yang dihasilkandari perbandingan antara ekspektasi (harapan) dengan kinerja (hasil)". (Usmara, 2003:231).

Definisi lain "Kualitas pelayanan adalah upaya pemenuhan kebutuhan dan keinginan pelanggan serta ketetapan penyampaiannya untuk mengimbangi harapan pelanggan". (Fandy Tjiptono, 2006:59).

Dari dua definisi diatas dapat disimpulkan bahwa kualitas pelayanan adalah suatu ukuran mengenai seberapa jauh pemenuhan kebutuhan yang diharapkan oleh pelanggan.

Faktor-faktor utama kualitas pelayanan menurut Fandy Tjiptono (2006:70) terdiri dari:

a. Tangibles (bukti fisik).

b. Reliability (keandalan).

c. Responsiveness (daya tanggap).

d. Assurance (jaminan).

e. Emphaty (empati).

Pengertian dari faktor-faktor utama kualitas pelayanan, yaitu:

a. Tangibles (bukti fisik), Meliputi fasilitas fisik, perlengkapan, pegawai, dan sarana komunikasi.

b. Reliability (keandalan), yakni kemampuan memberikan pelayanan yang di janjikan dengan segera, akurat dan memuaskan.

c. Responsiveness (daya tanggap), yaitu keinginan para staff untuk membantu para pelanggan dan memberikan pelayanan dengan tanggap.

d. Assurance (jaminan), mencagkup pengetahuan, kemampuan, kesopanan dan sifat dapat dipercaya yang dimiliki para staff, bebas dari bahaya, risiko, atau keragu-raguan.

e. Emphaty (empati), meliputi kemudahan dalam melakukan Sehubungan, komunikasi yang baik,perhatian pribadi, dan memahami kebutuhan para pelanggan.

\section{Pengertian Kepuasan}

Kepuasan bisa diartikan sebagai upaya pemenuhan sesuatu atau membuat sesuatu memadai (Tjiptono dan Chandra 2005:195).

Sedangkan menurut Kotler (2003:61) mendefinisikan “ Kepuasan sebagai perasaan antara persepsi kinerja atau hasil suatu produk dengan harapan-harapannya".

Dari definisi-definisi tersebut diatas dapat disimpulkan, yaitu adanya perbandingan antara harapan dan kinerja / hasil yang dirasakan pelanggan., diantaranya pengalaman berbelanja dimasa lampau, opini teman dan kerabat, serta informasi dan janji-janji perusahaan dan para pesaing.

Menurut Hadi Irawan (2004:57), adanya kepuasan pelanggan dapat memberikan beberapa manfaat, diantaranya :

a. Hubungan antara perusahaan dan para pelanggan yang akan menjadi harmonis

b. Memberikan dasar yang baik bagi pembelian ulang

c. Dapat mendorong terciptanya loyalitas pelanggan

d. Membentuk suatu rekomendasi dari mulut ke mulut (word of mouth) yang menguntungkan bagi pihak perusahaan

e. Reputasi perusahaan menjadi baik dimata pelanggan

f. Laba yang diperoleh meningkat

g. Dengan adanya pelanggan yang merasakan kepuasan atas pelayanan kita, dapat menarik pelanggan yang baru.

\section{Pengertian Pelanggan}

Menurut Zulian Yamit (2005:75) secara tradisional pelanggan diartikan orang yang membeli dan menggunakan produk.

Dalam perusahaan jasa, pelanggan adalah orang yang menggunakan jasa pelayanan, Pandangan tradisional ini menyimpulkan bahwa pelanggan adalah orang yang berinteraksi dengan perusahaan sebelum proses produksi selesai, karena mereka adalah pengguna produk. Sedangkan orang yang berinteraksi dengan perusahaan sebelum proses produksi berlangsung adalah dianggap sebagai pemasok.

Pelanggan dan pemasok adalah setiaporang atau badan yang datang dari dalam perusahaan. Selain itu tiga jenis pelanggan, yaitu :

1. Pelanggan internal (internal customer)

2. Pelanggan perantara (intermediate customer)

3. Pelanggan eksternal (external customer)

Pengertian tiga jenis pelanggan adalah : 
1. Pelanggan internal (internal customer) ialah setiap orang yang ikut menangani proses pembuatan maupun penyediaan produk didalam perusahaan atau organisasi.

2. Pelanggan perantara (intermediate customer) ialah mereka yang bertindak atau berperan sebagai perantara untuk mendistribusikan produk kepada pihak konsumen atau pelanggan eksternal. Pelanggan perantara ini bukan sebagai pemakai akhir.

3. Pelanggan eksternal (external customer) ialah pembeli atau pemakai akhir yang disebut sebagai pelanggan yang nyata (real customer).

Untuk memahami tiga jenis pelanggan tersebut maka munculah beberapa tipe karakteristik pelanggan yang berbeda-beda. Berikut adalah kiat-kiat dalam menghadapi pelanggan, berdasarkan 5 karakteristik yang umumnya ditemui :

1. Pelanggan yang pendiam

2. Pelanggan yang berpengalaman

3. Pelanggan yang bimbang

4. Pelanggan yang suka bicara

5. Pelanggan yang kurang memperhatikan

Pengertian tipe karakteristik pelanggan yang berbeda-beda sebagai berikut :

\section{Pelanggan yang pendiam}

Anda mungkin berpikir bahwa pelanggan yang pendiam adalah pelanggan yang kurang memperhatikan. Tidak jarang pelanggan ini semacam sesaat untuk memperhatikan apa yang sedang disampaikan oleh lawan bicaranya. Untuk menghadapinya, anda gunakan pertanyaan tertutup untuk menggali informasi dari pelangga. Batasi apa yang anda katakan dan tunggu untuk mendapatkan respon.

\section{Pelanggan yang berpengalaman}

Selain memperkenalkan pengalaman mereka menyediakan waktu untuk berdiskusi, anda akan memperolehkesempatan untuk mendapatkan pelanggan yang kooperatif dan setuju dengan ide-ide anda. Untuk menghadapinya, jangan membantah tapi bertanyalah. Dengarkan dan

jangan terlalu lama. Tunjukan rasa percaya diri saat menuntun pelanggan membuat keputusan.

\section{Pelanggan yang suka berbicara}

Anda harus tetap berhati-hati untuk tetap objektif dan tidak menjadi bingung. Untuk menghadapinya, penting sekali mendengarkan dengan penuh perhatian untuk dapat menggali informasi yang disampaikan pelanggan. Sebaiknya jangan membantah atau menyela. Dengarkan informasi penting dan menunggu untuk memberi jeda.

4. Pelanggan yang kurang memperhatikan

Pelanggan ini adalah seorang yang membutuhkan gangguan yang tidak perlu untuk melancarkan pembicaraan dengan anda. Untuk menghadapinya, perlu jeli untuk menemukan waktu yang tepat supaya tidak terkesan sebagai pengganggu. Gunakan nama pelanggan, alat bantu visual, ajukan pertanyaan, libatkan pelanggan. Denagn cara ini mungkin dapat mengembalikan perhatian pelanggan.

\section{Perilaku Pelanggan}

Perilaku dan sikap merupakan bagian yang sangat penting dalam etiket pelayanan. Perilaku dan sikap menunjukan kepribadian seseorang. Menurut Basu Dharmesta (2002:46) dalam Manajemen Pemasaran Sikap dan Perilaku yang harus dimiliki oleh setiap orang untuk menghadapi pelanggan adalah :

a. Jujur dalam bertindak dan bersikap

b. Rajin, tepat waktu, dan tidak pemalas

c. Murah senyum

d. Ramah

e. Sopan

f. Fleksibel

g. Memiliki rasa tanggung jawab

Tujuan utama pemasar yaitu melayani dan memuaskan hati pelanggan, kebutuhan, dan keinginan pelanggan. Oleh karena itu, pemasar perlu memahami bagaimana perilaku konsumen.

\section{Pengertian Kepuasan Pelanggan}

Menurut Tse dan Wilton (Fandy Tjiptono, 2006:146) mendefinisikan bahwa, Kepuasan pelanggan adalah respon pelanggan terhadap evaluasi ketidaksesuaian / diskonfirmasi yang dirasakan antara harapan sebelumnya (atau normal kinerja lainya) dan kinerja aktual produk yang dirasakan setelah pemakaiannya.

“Kepuasan pelayanan adalah hasil pendapat dan penilaian masyarakat terhadap kinerja pelayanan yang diberikan oleh aparatur penyelenggara pelayanan publik" (Ratminto dan Atik Septi Winarsih, 2009:224).

Sedangkan menurut Philip Kottler (2005:70)

"Kepuasan pelanggan adalah perasaan senang atau kecewa seseorang yang muncul setelah membandingkan persepsi atau kesannya terhadap kinerja atau hasil suatu produk dan harapan-harapan.

Dari beberapa definisi di atas dapat disimpulkan bahwa kepuasan pelanggan adalah segala sesuatu yang dirasakan dan diharapkan oleh pelanggan.

\section{Pengukuran Kepuasan Pelanggan}

Kepuasan pelanggan perusahaan perlu melakukan pemantauan dan pengukuran terhadap kepuasan pelanggan karena hal ini telah menjadi hal yang esensial bagi setiap perusahaan. Langkah tersebut dapat memberikan umpan balik dan masukan bagi keperluan pengembangan dan implementasi strategi peningkatan kepuasan pelanggan.

Menurut Fandy Tjiptono (2006:148), ada beberapa metode yang digunakan untuk mengukur kepuasan konsumen, yaitu :

a. System keluhan dan saran

b. Survei kepuasan pelanggan

c. Belanja siluman

d. Analisis pelanggan yang hilang 
Pengertian beberapa medode yang di gunakan untuk mengukur kepuasan konsumen adalah :

a. Sistem keluhan dan Saran

Setiap perusahaan yang berorintasi pada pelanggan perlu memberikan kesempatan seluas-luasnya bagi para pelanggan untuk menyampaikan saran, pendapat, dan keluhan mereka. Alur informasi ini memberikan banyak gagasan balik dan perusahaan dapat bergerak lebih cepat unt

b. Survei kepuasan pelanggan

Perusahaan mengukur kepuasan konsumen secara langsung dan perusahaan mengajukan pertanyaanpertanyaan atau menelepon konsumen menanyakan apakah mereka amat puas, puas, biasa saja, kurang puas, dan amat tidak puas terhadap kinerja karyawannya.

c. Belanja siluman

Peusahaan membayar seseorang bertindak sebagai pembeli potensial guna melaporkan hasil temuan mereka tentang kekuatan dan kelemahan yang meraka alami ketika membeli produk perusahaan dan produk asing, mereka dapat menyampaikan masalahmasalah tertentu untuk menguji apakah staf perusahaan menangani situasi tersebut dengan baik.

d. Analisis pelanggan yang hilang

Perusahaan-perusahaan harus menghubungi para pelanggan yang berhenti membeli atau mengganti pemasok, perusahaan harus mempelajari penyebabnya dan harus memperhatikan tingkat kehilangan pelanggan. Dimana jika meningkat menunjukan bahwa perusahaan gagal dalam memuaskan pelanggannya.

\section{Faktor-faktor Pendorong Kepuasan Pelanggan}

Berikut ini faktor pendorong yang membantu meningkatkan kepuasan pelanggan menurut Philip Kotler (2001:27), diantaranya :

a. Kualitas Produk

b. Harga

c. Service quality

d. Emotional factor

e. Biaya dan kemudahan

Pengertian dari factor pendorong yang membantu meningkatkan kepuasan pelanggan adalah :

a. Kualitas Produk, pelanggan akan merasa puas setelah membeli dan menggunakan yang baik, awet, atau tidak mudah rusak. Dalam kualitas produk ini ada enam elemen penting yaitu : performance, durability, feature, reability, consistency, dan design.

b. Harga, untuk pelanggan yang sensitif biasanya harga murah adalah suatu sumber kepuasan penting, karena mereka akan mendapatkan value of money yang tinggi. Komponen harga ini relative tidak penting yang tidak sensitif terhadap harga, untuk industri riteil harga ini sungguh penting dan kontribusinya terhadpa kepuasan relative basar

c. Service Quality, sangat tergantung kepada tiga hal yaitu : sistem, teknologi, dan manusia. Faktor manusia ini memegang kontribusi sekitar $70 \%$.

d. Emotional Factor, yang mendasari kepuasan pelanggan, misalnya rasa senang, rasa percaya diri, simbol sukses, bagian dari kelompok orang yang penting dan sebagainya.

e. Biaya dan kemudahan, untuk mendapatkan produk dan jasa tersebut. Pelanggan akan merasa semakin puas apabila produk yang di harapkannya relatif mudah, nyaman, dan efisien dalam mendapatkan produk ataupun pelayanan kita.

\section{METODOLOGI}

Metode penelitian yang digunakan adalah metode penelitian kuantitatif.

Menurut Sugiyono (2007:8) mendefinisikan bahwa "Metode kuantitatif adalah metode penelitian yang berlandaskan pada filsafat positivisme, digunakan untuk meneliti pada populasi atau sampel tertentu, pengumpulan data menggunakan instrument penelitian, analisas data bersifat kuantitatif atau statistik, dengan tujuan untuk menguji hipotesis yang telah ditetapkan".

Operasional variabel bertujuan untuk menjelaskan makna variabel penelitian. Variabel penelitian pada dasarnya adalah segala sesuatu yang berbentuk apa saja yang ditetapkan oleh peneliti untuk dipelajari sehingga diperoleh informasi tentang hal tersebut, kemudian ditarik kesimpulannya.

1. variabel independen / variabel bebas adalah merupakan variabel yang mempengaruhi atau yang menjadi sebab perubahannya atau timbulnya variabel dependen (variabel $X$ ). Variabel $X$ adalah kualitas pelayanan.

2. variabel dependen/variabel terikat adalah merupakan variabel yang dipengaruhi atau yang menjadi akibat, karena adanya variabel bebas (variabel Y). Variabel Y adalah kepuasan pelanggan.

Setiap variabel diukur berdasarkan indikator variabel. Indikator variabel adalah gejala yang tampak dan dapat diamati yang menunjukkan bahwa variabel itu terjadi.

Tabel 1

Definisi Operasional Variabel Antara Kualitas Pelayanan Terhadap Kepuasan Pelanggan Di PT. POS INDONESIA (PERSERO) CABANG SOREANG 40900

\begin{tabular}{|c|c|c|c|c|}
\hline variabel & Definisi & Sub Variabel & Indicator & $\begin{array}{c}\text { Skal } \\
\text { a }\end{array}$ \\
\hline
\end{tabular}




\begin{tabular}{|c|c|c|c|c|}
\hline $\begin{array}{l}(\mathrm{X}) \\
\text { Kualitas } \\
\text { Pelayanan }\end{array}$ & $\begin{array}{l}\text { Kualitas } \\
\text { adalah } \\
\text { kondisi } \\
\text { dinamis } \\
\text { yang } \\
\text { berhubunga } \\
\text { n dengan } \\
\text { produk, } \\
\text { jasa, } \\
\text { manusia, } \\
\text { proses dan } \\
\text { lingkungan } \\
\text { yang } \\
\text { memenuhi } \\
\text { atau } \\
\text { melebihi } \\
\text { harapan. } \\
\text { (Fandi } \\
\text { Tjiptono, } \\
\text { 2006:51). }\end{array}$ & 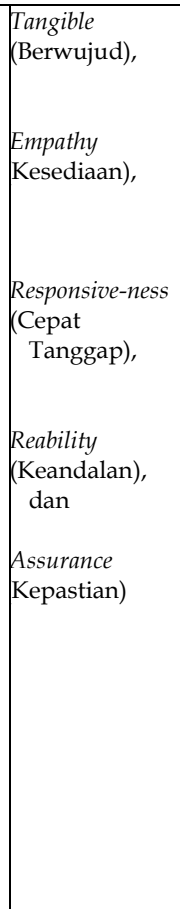 & $\begin{array}{l}\text { Kondisi dan tata } \\
\text { ruang kantor } \\
\text { Fasilitas yang di } \\
\text { berikan lengkap } \\
\text { / tidak } \\
\text { Menerima } \\
\text { keluhan } \\
\text { pelanggan } \\
\text { Peduli pada } \\
\text { pelanggan } \\
\text { Memberi solusi } \\
\text { pada pelanggan } \\
\text { Kemauan } \\
\text { membantu } \\
\text { pelanggan } \\
\text { Memberikan } \\
\text { jasa dengan } \\
\text { cepat dan sigap } \\
\text { Mengatasi } \\
\text { keluhan } \\
\text { pelanggan } \\
\text { Memberikan } \\
\text { pelayanan } \\
\text { akurat } \\
\text { Memberikan } \\
\text { layanan sesuai } \\
\text { janji } \\
\text { Dapat dipercaya } \\
\text { Kemampuan } \\
\text { dalam melayani }\end{array}$ & $\begin{array}{l}\text { Ord } \\
\text { inal }\end{array}$ \\
\hline
\end{tabular}

Menurut Sugiyono (2007:80) Pupolasi adalah "wilayah generalisasi yang terdiri atas objek / subjek yang mempunyai kualita dan karakteristik tertentu yang di tetapkan oleh peneliti untuk di pelajari dan kemudian di tarik kesimpulannya".

Populasi dalam penelitian ini adalah pelanggan PT.POS INDONESIA Cabang Soreang rata-rata perbulan 40 orang dari bulan september sampai oktober rata-rata per bulan adalah 40 orang (hasil wawancara dengan Bapak Deny Darmawan).

2. Sampel

Menurut Sugiyono (2007:81) Sampel adalah "bagian dari jumlah dan karakteristik yang dimiliki oleh populasi tersebut". Sehubungan dengan keterbatasan waktu dan biaya, penunulis mengambil sampel dan menggunakan rumus Slovin yang dikemukakan oleh Suliyanto (2006:10).

Dengan teknik Simple Random yaitu teknik pengambilan sampel yang sederhana (simple) karena pengambilan anggota sampel dari populasi dilakukan secara acak tanpa memperhatikan tingkatan atau strata yang ada dalam populasi tersebut, sebanyak 30 orang.

Dalam penulisan laporan ini penulis menggunakan beberapa metode dan teknik untuk pengumpulan datadata yang diperlukan. Antara lain :

1. Pengumpulan data primer

Pengumpulan data primer dilaksanakan dengan melakukan penelitian langsung ke lapangan. Pengumpulan data ini diperoleh dengan cara :

\section{a. Studi lapangan}

Yaitu teknik yang dilakukan oleh penulis dengan cara penulis terjun langsung ke lapangan untuk memperoleh data - data yang diperlukan.
b.
Wawancara

Pengertian teknik wawancara adalah teknik yang dilakukan untuk menggali lebih jauh atas permasalahan yang ada dengan membuat daftar wawancara yang relevan dengan pokok permasalahan yang di ungkapkan. Wawancara dilakukan dengan Bapak Deny Resmawan selaku Manajer Pelayanan.

c. Kuesioner

Yaitu memberikan daftar pertanyaan berdasarkan teori yang telah didapat oleh peneliti dalam bentuk kuesioner yang berkaitan dengan masalah yang diteliti. Dan berdasarkan teori yang digunakan dalam operasionalisasi variabel peneliti.

Tabel 2

Pilihan Jawaban Responden

\begin{tabular}{|c|c|}
\hline $\begin{array}{l}\text { Jawaban } \\
\text { pernyataan }\end{array}$ & Skor \\
\hline SS & 5 \\
S & 4 \\
KS & 3 \\
TS & 2 \\
STS & 1 \\
& \\
& \\
\hline
\end{tabular}

$\begin{array}{ll}\text { Keterangan: } & \\ \text { SS } & \text { : Sangat Setuju } \\ \text { S } & \text { : Setuju } \\ \text { KS } & \text { : Kurang Setuju } \\ \text { TS } & \text { : Tidak Setuju } \\ \text { STS } & \text { : Sangat Tidak Setuju }\end{array}$

Pengumpulan data sekunder

Pengumpulan data sekunder dilakukandengan cara studi kepustakaan yaitu penulis mempelajari dan meneliti hubungan yang ada kaitannya dengan pengaruh kualitas pelayanan terhadap kepuasan pelanggan di PT.POS INDONESIA (PERSERO) Cabang Soreang 40900.

Untuk menguji pengaruh kualitas pelayanan terhadap kepuasan pelanggan di PT.POS INDONESIA (PERSERO) Cabang Soreang 40900. penulis menggunakan rumus:

\section{Korelasi Spearman Rank}

Penghitungan koefisien korelasi antara $X$ dan $Y$ dicari dengan menggunakan rumus Korelasi Spearman, di mana alat analisis ini dipilih berdasarkan bentuk data yang akan diolah adalah berskala ordinal. Sebelum dapat menghitung besarnya koefisien korelasi Spearman, maka terlebih dahulu dicari nilai faktor koreksi (T), karena analisis data mentah menunjukkan adanya data kembar. Rumus untuk menghitungnya adalah sebagai berikut:

$$
\begin{aligned}
& \sum \mathrm{Tx}=\frac{\mathrm{tx}^{3}-\mathrm{tx}}{12} \\
& \sum \mathrm{Ty}=\frac{\mathrm{ty}^{3}-\mathrm{ty}}{12}
\end{aligned}
$$

Di mana :

$\mathrm{Tx}=$ Faktor Koreksi yang dicari pada variabel $\mathrm{X}$ 
Ty = Faktor Koreksi yang dicari pada variabel $\mathrm{Y}$

ty/tx = Banyaknya observasi yang berangka sama setiap rangking

Dengan demikian, maka perhitungan koefisien korelasi Spearman antara $X$ dan $Y$ adalah sebagai berikut:

$$
\begin{aligned}
& \mathrm{rs}=\frac{\sum \mathrm{X}^{2}+\sum \mathrm{Y}^{2}-\sum \mathrm{Di}^{2}}{2 \sqrt{\sum \mathrm{X}^{2} * \sum \mathrm{Y}^{2}}} \\
& \sum \mathrm{X}^{2}=\frac{\mathrm{N}^{3}-\mathrm{N}}{12}-\sum \mathrm{TX} \\
& \sum \mathrm{Y}^{2}=\frac{\mathrm{N}^{3}-\mathrm{N}}{12}-\sum \mathrm{Ty}
\end{aligned}
$$

Di mana :

rs $=$ Koefisien Korelasi Rank Spearman

$\Sigma X^{2}=$ Skor variabel $X$ setelah Faktor Koreksi

$\Sigma Y^{2}=$ Skor variabel $Y$ setelah Faktor Koreksi

$\mathrm{Di}^{2}=$ Selisih dua rangking

\section{Koefisien Determinasi}

Koefisien determinasi ini diperlukan untuk melihat seberapa besar pengaruh variabel $X$ terhadap variabel Y. Perhitungannya diperoleh dengan cara mengkuadratkan koefisien korelasi.

$$
\mathrm{KD}=\mathrm{rs}^{2} \times 10
$$

\section{HASIL DAN PEMBAHASAN}

Kualitas apabila dikelola dengan tepat mampu memberikan kontribusi positif terhadap terwujudnya loyalitas pelanggan sehingga perusahaan dapat meningkatkan kepuasan pelanggan dan meminimumkan atau meniadakan pengalaman yang kurang menyenangkan kepada pelanggan.

Untuk mewujudkan sebuah layanan yang dapat memberikan kepuasan kepada pelanggan diperlukan adanya sebuah standarisasi atau aturan yang dapatdijadikan sebagai pedoman terhadap kualitas tersebut. PT. POS INDONESIA (PERSRO) Cabang Soreang mempunyai standarisasi pelayanan yang harus di terapkan olea pegawai -pegawai nya, hal ini diharapkan dapat memberikan kepuasan kepada pelanggan yang akan menggunakan jasa / produk PT. POS INDONESIA (PERSERO) Cabang Soreang.

Adapun standar pelayanan itu adalah :

1. Standar pelayanan loket

Pelayanan loket berada di depan di maksudkan agar pelanggan yang mau bertransaksi lebih mudah dan dekat tanpa harus masuk / melewati bagian lain terlebih dahulu. Standar pelayanan yang dilakukan oleh petugas loket adalah :

a. Setiap petugas loket harus menggunakan prinsip $3 \mathrm{~S}$ (Senyum, Sapa, Salam).

b. Ramah dan peduli terhadap pelanggan.

c. Responsibility (cepat tanggap)

Setiap petugas loket harus cepat dan tanggap dalam melayani kebutuhan setiap pelanggan yakni melayani pelanggan yang akan membeli benda pos, menerima kiriman surat / paket baik domestic maupun luar negeri, melayani pengiriman uang dan pembayaran uang (wesel), melayani penagihan listrik.

d. Melayani dengan setulus hati.

e. Setiap petugas loket harus memberikan informasi kepada pelanggan secara jelas.

f. Customer focus (fokus terhadap pelanggan) menganggap pelanggan adalah sebagai utama.

Pelanggan terbagi menjadi 2, yaitu :

1. Pelanggan external (Pelanggan dari luar atau Public).

2. Pelanggan internal (Pelanggan dari dalam atau rekan kerja kita sendiri).

2. Standar Tempat Kerja

Pada umumnya nuansa kerja haruslah bersih dan rapi tujuan ini dimaksudkan agar para pegawai bekerja tercipta suasana yang nyaman sehingga para pegawai bekerja dengan baik.

Standar tempat kerja di bagian loket, yaitu :

1. Computer berfungsi dengan baik.

2. ATK (alat tulis kantor).

3. Telepon.

4. Lemari arsip.

5. Mesin antrian.

6. Ruang tunggu.

7. Kertas informasi.

8. Meja untuk menulis.

Standar tempat kerja di bagian pengantar surat, yaitu :

1. Alat tulis.

2. Tas / kantong antaran.

3. Jacket dan helm.

4. Kendaraan mobil / motor.

Standar sikap pelayanan

Dalam sebuah perusahaan jasa tentunya mempunyai standar sikap pelayanan yang telah di tetapkan dimaksudkan agar petugas yang berada di bagian front office (loket) maupun di bagian back office bisa memberikan pelayanan yang baik kepada pelanggannya.

Standar sikap pelayanan di bagian front office adalah :

a. Menyambut pelanggan dengan prinsip $3 \mathrm{~S}$ (senyum, salam, sapa).

b. Menanyakan keperluan pelanggan dengan mengucapkan “ ada yang bisa saya bantu".

c. Memberikan informasi kepada pelanggan.

d. Mengucapkan terima kasih dan salam kepada pelanggan.

Standar pelayanan di bagian back office / di bagian pengantar adalah :

a. Mematikan kendaraan mobil /motor ketika sampe tujuan.

b. Turun dari kendaraan.

c. Untuk antaran ke rumah mengetuk pintu sambil mengucapkan salam "POS".

d. Untuk antrin ke kantor / gedung perkantoran awali dengan 3 S (Senyum, Salam, Sapa).

e. Melakukan greeting setelah dibukakan pintu.

f. Menyerahkan paket dengan ke 2 tangan.

g. Meminta pelanggan untuk mentandatangani bukti serah terima.

h. Mengucapkan terimakasih dan salam sebelum meningalkan pelanggan.

i. Tidak boleh meminta tips kepada pelanggan petugas yang berada di bagian tersebut. 
Standar penerimaan telepon

Dalam sebuah perusahaan standar penerimaan telepon merupakan salah satu aspek penting dari sekian standar pelayanan yang di tetapkan dalam mendapatkan citra yang baik dalam pelayanan.

Adapun standar pelayanan telepon yakni :

a. Segera angkat telepon sebelum berdering untuk yang ke 3 kalinya.

b. Jawablah telepon dengan menyebutkan identitas diri operator. Sebagai contoh : "Selamat pagi ! PT.POS INDONESIA Cabang Soreang dengan Ismi ati bisa saya bantu?"

c. Menanyakan nama pelanggan dan mengucapkan nama pelanggan untuk percakapan selanjutnya.

d. Petugas menanyakan tentang apa yang di inginkan oleh pelanggan.

e. Mengucapkan terima kasih dan salam sebelum mengakhiri percakapan.

f. Sebaiknya pelanggan menutup tetepon terlebih dahulu.

Standar penampilan petugas

Standar penampilan pegawai mempunyai standar / aturan Untuk persentase pelaksanaan kualitas pelayanan dengan dipatuhi oleh pegawai, dimaksudkan agar terciptanya kepuasạm terh skor ideal (kriterium) sebesar 600, sedangkan kepuasan pelanggan pada saat melayani pelanggan dan mengahtar surathy gdiperoleh dari hasil penelitian adalah 438, paket yang di kirimkan.

Standar penampilan pelayan loket dan petugas pengantar adalah

a. Berseragam sesuai dengan standar yang ditetapkan, yakni :

- Hari senin sampai rabu memakai celana berwarna gela berwarna putih.

- Hari kamis memakai baju promosi (Baju yang berlogo “ POS "

- Hari jumat memakai baju batik

- Hari sabtu memakai baju bebas tetapi rapih

b. Menggunakan ID Card

c. Wajah bersih

d. Rambut pendek dan rapi ( laki - laki ), rambut di cepol ( pere

e. Kumis pendek dan jenggot di cukur habis (laki - laki )

\section{Kepuasan Pelanggan di PT. Pos Indonesia Cabang Soreang}

Berdasarkan hasil keseluruhan perhitungan kuesioner variabel $\mathrm{Y}$ di atas terbagi ke dalam lima kategori penilaian, yaitu : SS (Sangat Setuju), S (Setuju), KS (Kurang Setuju), TS (Tidak Setuju), STS (Sangat Tidak Setuju), maka selanjutnya dapat diberikan skor / pembobotan dengan menggunakan skala likert pada Tabel 3.6 untuk melihat kecenderungan jawaban responden yang dianalisis sebagai berikut :

Tabel 3

Rekapitulasi Skor Variabel Kepuasan Pelanggan (Y)

\begin{tabular}{|c|c|c|c|c|c|c|}
\hline \multirow{2}{*}{$\begin{array}{c}\text { Nomor } \\
\text { Item }\end{array}$} & \multicolumn{5}{|c|}{ Alternatif Jawaban } & \multirow{2}{*}{} \\
\cline { 2 - 6 } & SS & S & KS & TS & STS & Jumlah \\
\hline $\mathbf{1}$ & 0 & 60 & 45 & 0 & 0 & $\mathbf{1 0 5}$ \\
\hline $\mathbf{2}$ & 15 & 72 & 27 & 0 & 0 & $\mathbf{1 1 4}$ \\
\hline $\mathbf{3}$ & 15 & 68 & 30 & 0 & 0 & $\mathbf{1 1 3}$ \\
\hline $\mathbf{4}$ & 10 & 52 & 42 & 2 & 0 & $\mathbf{1 0 6}$ \\
\hline
\end{tabular}

\begin{tabular}{|l|l|l|l|l|l|l|}
\hline Jumlah & 40 & 252 & 144 & 2 & 0 & 438 \\
\hline
\end{tabular}

Sumber : Hasil pengolahan Data MS. Exell

Kepuasan Pelanggan di PT. Pos Indonesia Cabang Soreang

Berdasarkan kumulatif skor diatas, akan diketahui kategori dalam variabel pengaruh kepuasan pelanggan. Dengan setiap dimensi yang terdri daribervariasi ítem pernyataan / indikator, maka pengkategorian tersebut dilakukan berdasarkan interval batasan cara sebagai berikut :

Nilai indeks mínimum

Nilai indeks maksimum

$: 4 \times 30 \times 1=120$

Interval

Jarak Interval

$: 4 \times 30 \times 5=600$

$: 600-120=480$

$: 480: 5=96$

Perhitungan Frekuensi Variabel Y : 438

Dengan interval batasan tersebut di atas, maka secara kontinum dapat di gambarkan sebagai berikut :

Dari hasil perhitungan pada Tabel 3.4, skor total untuk variable pengaruh kualitas pelayanan adalah sebesar 438, berada pada rentang antara 408 dan 504 yang terletak pada kategori tinggi. maka berdasarkan data yang ada ata-rata frekuensi mengenai pelayanan adalah : (438:600) x 100\% = 73 $\%$,artinya bahwa pelayanan pegawai di PT.Pos Indonesia Cabang Soreang yang di berikan sudah mencapai $73 \%$ dapat dikatakan bahwa kepuasan Pelanggan di PT.Pos Indonesia Cabang Soreang sudah baikberdasarkan penilaian dari 30 responden.

Dari data-data yang di peroleh melalui pembagian kuesioner kepada sejumlah 30 pelanggan, yaitu data mengenai kualitas pelayanan sebagai variabel $X$ dan kepuasan pelanggan sebagai variabel $Y$, maka untuk menganalisis hubunan kedua variabel tersebut digunakan metode - metode statistik seperti yang telah dijelaskan pada bab sebelumnya.

Sebelum menganalisis hubungan kedua variabel, maka kuesioner yang dibagikan diolah dalam bentuk tabel tabel yang terdapat dalam lampiran, kemudian dilakukan pengukuran yaitu analisis koefisien korelasi rank spearman dan analisis koefisien determinasi untuk mengetahui seberapa besar pengaruh kualitas pelayanan terhadap kepuasan pelanggan di PT. Pos Indonesia Cabang Soreang.

\section{Hasil Analisis Berdasarkan Rumus Korelasi Rank Spearman}

Perhitungan Koefisien korelasi antara X dan $Y$ dianalisis dengan menggunakan rumus korelasi spearman, dimana alat analisis ini dipilih berdasarkan bentuk data yang akan berskala ordinal. Untuk itu dilakukan penyusunan data skor setiap variabel menjadi urutan atau rangking. 


\section{Analisis Koefisien Korelasi Rank Spearman}

Perhitungan koefisien korelasi rank spearman dilakukan untuk menghitung seberapa besar hubungan antara variabel $\mathrm{X}$ dan variabel $\mathrm{Y}$. berdasarkan daa hasil pembagian kuesioner terhadap 30 responden yang telah diolah ke dalam bentuk tabel jawaban responden yang telah di jumlahkan dan di beri rangking, sehingga diperoleh nilai $\sum \mathrm{di}^{2}$ yang dapat dilihat pada lampiran.

Dari tabel yang terdapat pada lampiran tersebut diperoleh $\sum \mathrm{di}^{2}=192$, karena jumlah rank kembar dalam variabel $X$ dan variabel $Y$ cukup banyak, maka untuk mencari besarnya korelasi rank spearman dengan menggunakan rumus $r$ untuk rank kembar sbagai berikut

$$
\mathrm{rs}=\frac{\sum \mathrm{X}^{2}+\sum \mathrm{Y}^{2}-\sum \mathrm{Di}^{2}}{2 \sqrt{\sum \mathrm{X}^{2} * \sum \mathrm{Y}^{2}}}
$$

Untuk menyelesaikan rumus tersebut, sebelumnya harus di cari dulu nilai

$\sum X^{2}$ dan $\sum Y^{2}$ berdasarkan data skor sama variabel $X$ dan variabel Y dengan menggunakan rumus sebagai berikut :

Untuk variabel $\mathrm{X}$ dan $\mathrm{Y}$ adalah :

$$
\begin{aligned}
& \sum \mathrm{Tx}=\frac{\mathrm{tx}^{3}-\mathrm{tx}}{12} \\
& \sum \mathrm{Ty}=\frac{\mathrm{ty}^{3}-\mathrm{ty}}{12}
\end{aligned}
$$

dan

Kemudian kita cari $\sum \mathrm{X}^{2}$ dan $\sum \mathrm{Y}^{2}$, dengan perhitungan

sebagai berikut :

$$
\begin{aligned}
\sum \mathrm{X}^{2} & =\frac{\mathrm{N}^{3}-\mathrm{N}}{12}-\sum \mathrm{Tx} \\
\sum \mathrm{X}^{2} & =\frac{30^{3}-30}{12}-35 \\
& =2212.5 \\
\sum \mathrm{Y}^{2} & =\frac{\mathrm{N}^{3}-\mathrm{N}}{12}-\sum \mathrm{YX} \\
\sum \mathrm{X}^{2} & =\frac{30^{3}-30}{12}-170 \\
& =2077,5
\end{aligned}
$$

Selanjutnya dihitung koefisien Rank spearman antara kedua variabel tersebut, yaitu sebagai berikut :

$$
\begin{gathered}
\mathrm{rs}=\frac{\sum \mathrm{X}^{2}+\sum \mathrm{Y}^{2}-\sum \mathrm{Di}^{2}}{2 \sqrt{\sum \mathrm{X}^{2} * \sum \mathrm{Y}^{2}}} \\
\mathrm{rs}=\frac{2212.5+2077.5-192}{2 \sqrt{2212.5 * 2077.5}} \\
\mathrm{rs}=\frac{4098}{2 \sqrt{2143.9}} \\
\mathrm{rs}=\frac{4098}{4287.8}
\end{gathered}
$$

rS $=0.955$

Dari hasil analisis di atas, diperoleh nilai koefisien korelasi rank spearman sebesar $0.955 \quad 7, \quad$ yang artinya setelah di konsultasikan pada tabel 2.4 menunjukna adanya hubungan yang "Sangat Kuat " antara Kualitas pelayanan dengan Kepuasan Pelanggan.

Analisis Koefisien Determinasi

Selanjutnya untuk mengrtahui besarnya kontribusi yang diberikan oleh variabel $X$ (Kualitas Pelayanan) terhadap variabel Y (Kepuasan Pelanggan) dapat diketahui dengan menganalisis koefisien determinasi dengan perhitungan sebagai berikut :

$$
\begin{aligned}
& \mathrm{KD}=\mathrm{rs}^{2} \times 100 \% \\
& \mathrm{KD}=(0.9557)^{2} \times 10 \\
& \mathrm{KD}=91.33 \%
\end{aligned}
$$

Dari hasil analisis koefisien determinasi di atas, diketahui bahwa Kualitas Pelayanan (X) memberikan kontribusi sebesar yaitu $91.33 \%$ terhadap Kepuasan Pelanggan (Y), dan sisanya $8.67 \%$. ditentukan oleh factor lain yang tidak diteliti dalam penelitian misalnya kondisi Keuangan, Sosial budaya dan lain - lain.

Tabel 4

Pedoman untuk memberikan interpretasi koefisien korelasi

\begin{tabular}{|c|c|}
\hline $\begin{array}{c}\text { Interval Koefisien } \\
\text { Korelasi }\end{array}$ & Tingkat Hubungan \\
\hline $0,00-0,199$ & Sangat Rendah \\
\hline $0,20-0,399$ & Rendah \\
\hline $0,40-0,599$ & Sedang \\
\hline $0,60-0,799$ & Kuat \\
\hline $0,80-1,000$ & Sangat Kuat \\
\hline
\end{tabular}

Sumber : Sugiyono, 2007

Berdasarkan hasil penelitian maka dapat di gambarkan peradigma penelitian sebagai berikut :

Gambar 3.4

Paradigma Hasil Penelitian

$91,33 \%$

8.67

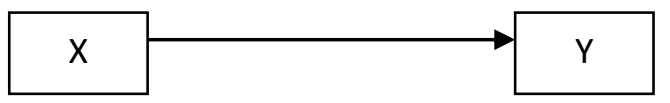


Permasalahan Yang Timbul dalam Pengaruh Kualitas Pelayanan Terhadap Kepuasan Pelanggan di PT. Pos Indonesia (PERSERO) Cabang Soreang 40900

Pada saat melakukan pelayanan, PT. Pos Indonesia (PERSERO) Cabang Soreang mengalami beberapa hambatan. Factor - factor yang menghambat tersebut antara lain :

1. Pada pelayanan I-Pos atau pelayanan surat menyurat, masih banyak pelanggan yang kurang memahami tentang standarisasi pengiriman surat, dokumen dan barang.

2. Belum adanya kotak saran maupun keluhan untuk pelnaggan, sehingga pegawai sulit untuk mengukur kepuasan pelanggan.

Upaya Pemecahan Masalah Dalam Menghadapi Permasalahan Yang Timbul Dalam Pengaruh Kualitas Pelayanan Terhadap Kepuasan Pelanggan di PT. Pos Indonesia (PERSERO) Cabang Soreang 40900

Upaya yang di lakukan untuk mengatasi masalah yang timbul adalah :

1. Dalam pelayanan I-Pos atau pelayanan surat menyurat, masih banyak pelanggan yang kurang memahami tentang standarisasi pengiriman surat, dokumen dan barang. Upaya ynag di lakukan oleh PT. Pos Indonesia Cabang Soreang ialah pegawai PT. Pos Indonesia cabang Soreang menginformasikan dengan jelas tentang standarisasi dalam pengiriman dokumen atau barang

2. Belum adanya kotak saran maupun atau keluhan untuk pelanggan. Upaya yang di lakukan oleh PT. Pos Indonesia Cabang Soreang adalah adanya bagian customer service pagawai bagian loket, sehingga konsumen yang mendapat permasalahan agar dapat langsung berkomunikasi.

\section{E. KESIMPULAN DAN SARAN}

Kesimpulan yang didapat dari penelitian mengenai pengaruh kualitas pelayanan teradap kepuasan pelanggan di PT. Pos Indonesia Cabang Soreang adalah sebagai berikut :

a. Berdasarkan analisis kualitas pelayanan di PT. Pos Indonesia Cabang Soreang sudah mencapai 77,16 \%, artinya pelaksanaan kualitas pelayanan di PT. POS INDONESIA (PERSERO) Cabang Soreang sudah baik.

b. Berdasarkan analisis kepuasan pelanggan di PT. Pos Indonesia Cabang Soreang sudah mencapai $73 \%$, artinya pelaksanaan kualitas pelayanan di PT. POS INDONESIA (PERSERO) Cabang Soreang sudah baik.

c. Hubungan antara korelasi antara kualitas pelayanan terhadap kepuasan pelanggan di PT. Pos Indonesia cabang Soreang dengan analisa Rank Spearman adalah 0.955 artinya hubungan antara dua variabel sangat kuat. Selain itu pengaruh kualitas pelayanan terhadap kepuasan pelanggan di PT. Pos Indonesia Cabang Soreang $91.33 \%$, dan sisanya 8,67\% ditentukan oleh faktor lain yang tidak di teliti dalam penelitian misalnya kondisi keuangan, social dan Budaya.

\section{F. DAFTAR PUSTAKA}

Barata, Atep Adya.2004. Dasar - dasar Pelayanan Prima. Jakarta : PT.Elex Komputindo.

Irawan, Handi.2004. 10 Prinsip Kepuasan Pelanggan. Jakarta : PT. Elex Media Komputindo.

Kottler, Philip. 2005. Manajemen Pemasaran. Yogyakarta : Graha Ilmu.

Ratmino dan Atik septi Winarsih. 2008. Manajemen Pelayanan. Jakarta : Pustaka Pelajar.

Rahmayanti, Nina.2010. Manajemen Pelayanan Prima. Yogyakarta : Graha Ilmu.

Sugiyono.2007. Metode Penelitian Kuantitatif Kualitatif dan R\&D. Bandung : Alfabeta

Susilowati, Rini. 2018. Analisa Kualitas Pelayanan dan Kepuasan Pelanggan untuk Meningkatkan Perkembangan Bisnis, Jurnal MABIS Ama darmala, Yogyakarta

Tjiptono, Fandi dan Gregorius Candra. (2005). Service, Quality, and Satisfaction. Yogyakarta : Andi Offset.

Veranita, Mira.2012. Pengaruh Pemberdayaan Pegawai terhadap Efektivitas Kerja pada PT Pos Indonesia (Persero), Jurnal Bisnis Wirausaha ISSN 1693-234X Volume 7 No.1, FISIP, Unpas 
